\title{
DAMPAK NILAI PELANGGAN DAN RELATIONSHIP MARKETING DALAM MEMBANGUN KEPUASAN PELANGGAN MELALUI CITRA MEREK SEBAGAI VARIABEL INTERVENING
}

\author{
Ramdani Bayu Putra, Fitri Yeni, Hasmaynelis Fitri,Yagus Valentino Harefa, Neni Sri Wayuni \\ Ningsih, Agung Ramdhanu, Hadi Syahputra \\ Email : ramdhani_bayu@upiyptk.ac.id
}

\begin{abstract}
Abstrak
Penelitian ini bertujuan untuk mengetahui seberapa besar Pengaruh Nilai Pelanggan dan Relationship Marketing dalam membangun Kepuasan Pelanggan melalui Citra Merek sebagai variabel interverning keripik balado bintang jaya 4 × 7 Padang.Metode yang digunakan adalah Structur Equation Modeling (SEM) dengan Partial Least Square (PLS).Dengan mengedarkan kuesioner sebanyak 85 responden.

Hasil analisis datamenimpulkan, terdapat pengaruh positif yang signifikan antara variabel.nilai pelanggan terhadap variabel citra merek. Terdapat pengaruh positif dan signifikan variabel relationship antara variabel citra merek. Terdapat pengaruh positif dan signifikan variabel relationship marketing terhadap variabel kepuasan pelanggan.sedangkan variabel nilai pelanggan tidak berpengaruh positif dan signifikan terhadap variabel kepuasan pelanggan. Terdapat pengaruh positif dan signifikan variabel nilai pelanggan terhadap variabel kepuasan pelanggan melalui variabel citra merek.Terdapat pengaruh positif dan signifikan variabel relationship marketing terhadap variabel kepuasan pelanggan melalui variabel citra merek.
\end{abstract}

\section{Kata Kunci: Nilai Pelanggan, Relationship Marketing, Kepuasan Pelanggan, Citra Merek}

\section{Pendahuluan}

Perkembangan bisnis kuliner pada saat sekarang ini semakin lama persaingan semakin ketat, misalnya saja persaingan bisnis dalam usaha makanan yang memiliki ciri khas dan cita rasa yang unik. Hal ini membuat dunia usaha akan mempercepat meningkatkan citra dengan memunculkan inovasi serta kreatifitas karena adanya tuntutan di dalam dunia bisnis untuk lebih memahami perilaku dari setiap karakter pelanggan. Sehingga mampu melayani kebutuhannya dengan cara pandangan yang luas sebagai pencapaian terbaik bagi perusahaan dapat memuaskan para pelanggan, seperti dalam istilah yaitu produsen berwawasan konsumen memiliki berbagai akses mendapatkan suatu informasi dibutuhkan mengenai kelebihan dan kekurangan produk mereka inginkan.

Menurut Zeithaml et al (2013 : 80)defenisi dalam kepuasan pelanggan adalah tanggapan pemenuhan konsumen, yaitu suatu pertimbangan bahwa barang atau jasa itu sendiri, memberikan suatu tingkat pemenuhan terkait konsumsi yang menyenangkan. Dengan memahami kepuasan pelanggan dan memahami setiap peluang yang baru muncul dari belum terpenuhi sesuai dengan harapan dan keinginan bagi kebutuhan konsumen.

Nilai pelanggan (customer value) sebagai preferensi perceptual dan evaluasi pelanggan terhadap atribut produk kinerja atribut, dan konsekuensi yang didapatkan dari pemakaian produk yang memfasilitasi pencapaian tujuan dan sasaran dalam situasi pemakaian. Dan nilai pelanggan sebagai penilaian keseluruhan konsumen terhadap kepuasan yang dicapai oleh sebuah produk berdasarkan persepsi nya terhadap apa yang telah diterima dan apa yang telah diberikan, (Tjiptono, 2014 : 353).

Relationship marketing adalah membangun hubungan jangka panjang yang saling memuaskan dengan pihak - 
pihak kunci, untuk mendapatkan dan mempertahankan bisnisKotler dan Keller (2013:20) dan Kotler dan Amstrong ( 2014:34 ) relationship marketing adalah keseluruhan proses membangun dan mempertahankan hubungan pelanggan yang menguntungkan dengan memberikan nilai pelanggan dan kepuasan pelanggan.

Citra merek ( brand image ) merupakan aspek yang sangat penting dari merek. Citra merek adalah identitas (termasuk personalitas, simbol, proposisi nilai, brand essence, dan posisi merek). Citra merek dan asosiasi merek adalah merupkan persepsi konsumen yang mungkin atau mungkin tidak merefleksikan realitas objektif.dalam positioning perusahaan, citra merekmerupakan salah satumetode yang digunakan Ismail (2012: 62)

Data Penjualan Keripik Balado 4 x 7 Padang
Tahum 2014-2018
\begin{tabular}{|c|c|c|}
\hline Tahum & Jumlah ( Rp ) & $\begin{array}{c}\text { Persentase } \\
\mathbf{( \% )}\end{array}$ \\
\hline 2014 & Rp.934.600.000,- & - \\
\hline 2015 & Rp.1.015.900.000,- & $8,7 \%$ \\
\hline 2016 & Rp.1.064.300.000,- & $4,8 \%$ \\
\hline 2017 & Rp.978.150.000,- & $-8,1 \%$ \\
\hline 2018 & Rp.956.750.000,- & $-2,2 \%$ \\
\hline
\end{tabular}
Sumber: Keripik Balado 4 x 7 Padang, Tahhun 2019

Berdasarkan volume penjualan pada tabel 1.1 diatas dapat disimpulkan bahwa volume penjualan keripik balado 4 x 7 Padang tahun 2014 volume penjualannya sebesar Rp.934.500.000, tahun 2015 volume penjualan meningkat menjadi Rp.1.015.800.000 persentase penjualannya menjadi8,7\%, pada tahun 2016 volume penjualan meningkat menjadi Rp.1.064.300.000 yang persentase penjualannya menjadi4,8\%, kemudian pada tahun 2017 volume penjualan menurun menjadi Rp. 978.150.000 yang persentase penjualannya menjadi $8,1 \%$,dan pada tahun 2018 volume penjualan meningkat menjadi Rp.956.750.000yang persentase penjualannya menjadi $-2,2 \%$.

Dari hal tersebut, terindikasi volume penjualan berfluktuasi berarti kepuasaan pelanggan keripik balado 4 x 7 Padang tidak optimal disinyalir disebabkan oleh Nilai Pelanggan, Relationship Marketing dan Citra Merek. Nilai pelanggan di berikan konsumen kepada usaha kerpik balado 4 × 7 Padang harus mampu mengevaluasi setiap kelemahan dan kekurangan dari usaha agar mampu menaikan citra merek dan kinerja usaha tersebut agar lebih baik kedepannya. Oleh karena itu bedasarkan dari latar belakang masalah diatas maka penulis memutuskan untuk melakukan penelitian yang berjudul Pengaruh Nilai Pelanggan dan Relationship Marketing dalam membangun Kepuasaan Pelanggan melalui Citra Merek sebagai variabel intervening pada pada keripik balado bintang jaya $4 \mathrm{x}$ 7 Padang.

Berdasarkan latar belakang masalah yang telah diuraikan sebelumnya, maka rumusan masalah penelitian ini adalah :
1. Bagaimana Nilai pelanggan berpengaruh terhadap Kepuasaan Pelanggan pada keripik balado bintang jaya 4 x 7 Padang?

2. Bagaimana Relationship Marketing berpengaruh terhadap Kepuasaan Pelanggan pada keripik balado bintang jaya 4 x 7 Padang?

3. Bagaiman Nilai Pelanggan dan Relationship Marketing berpengaruh terhadap Citra Merek pada keripik balado bintang jaya $4 \times 7$ Padang?

4. Bagaimana Nilai Pelanggan berpengaruh terhadap Citra Merek pada keripik balado bintang jaya 4 x 7 Padang?

5. Bagaimana Relationship Marketing berpengaruh terhadap Kepuasaan Pelanggan pada keripik balado bintang jaya 4 x 7 Padang?

6. Bagaimana Nilai Pelanggan berpengaruh terhadap Kepuasaan Pelanggan melalui Citra Merek pada keripik balado bintang jaya $4 \quad$ x 7 Padang?

7. Bagaimana Relationship Marketing berpengaruh terhadap Kepuasan 
Pelangganmelalui Citra Merek pada keripik balado bintang jaya $4 \times 7$ Padang?

\section{Telaah Literatur}

\section{Kepuasan Pelanggan (Y)}

Menurut Fandy Tjiptono (2014:353), memberikan definisi tentang kepuasan pelanggan, yaitu "Kepuasan pelanggan adalah respon emosional terhadap pengalaman-pengalaman berkaitan dengan produk atau jasa tertentu yang dibeli, gerai ritel, atau bahkan pola perilaku (seperti perilaku berbelanja dan perilaku pembeli), serta pasar secara keseluruhan".Pemahaman terhadap harapan-harapan pelanggan oleh supplier merupakan input untuk melakukan perbaikan dan peningkatan kualitas produk baik barang maupun jasa. Kunci keputusan pelanggan berkaitan dengan kepuasan terhadap penilaian produk barang dan jasa.Kerangka kepuasan pelanggan terletak pada kemampuan supplier dalam memahami kebutuhan, keinginan dan harapan pelanggan sehingga penyampaian produk baik barang maupun jasa sesuai dengan harapan pelanggan.Selain faktorfaktor tersebut di atas, dimensi waktu juga mempengaruhi tanggapan atau persepsi pelanggan terhadap kualitas produk yang ditawarkan.

\section{Nilai Pelanggan $\left(\mathrm{X}_{1}\right)$}

Menurut Kotler \& Keller (2012:125) definisi dari nilai pelanggan adalah "Hasil penilaian atas prespektif konsumen mengenai perbedaan dari semua manfaat yang didapat oleh konsumen dengan biaya yang ditawarkan dibandingkan pada alternatifnya".

Customer value yang diwakili oleh total produk yang meliputi keseluruhan nilai dalam suatu produk atau jasa yang kemudian dilempar ke pasar sasaran untuk kemudian pasar sasaran tersebut melakukan proses pengambilan keputusan berdasarkan persepsi mereka terhadap nilai yang dirasakan. Perusahaan diyakini akan jauh lebih besar apabila harus menarik pelanggan baru atau pelanggan yang sudah meninggalkan perusahaan, dari pada mempertahankannya. Menurut Fandy Tjiptono (2014:308) customer value tidak hanya mencakup kualitas, namun juga sebuah harga. Sebuah jasa tertentu bisa saja memiliki kualitas unggul, namun dievaluasi bernilai rendah karena harganya terlampau mahal.

\section{Relationsip Marketing ( $\mathbf{X}_{2}$ )}

Menurut Kotler dan Keller (2013:20) membangun hubungan jangka panjang yang saling memuaskan dengan pihak pihak kunci, untuk mendapatkan dan mempertahankan bisnis mereka. Palmatier (2008) dalam Sonkova dan Grabowska (2015:197) mendefinisikan pemasaran (relationship marketing)adalah proses identifikasi, mengembangkan, memelihara, dan permutasian dengan tujuan meningkatkan kinerja. Menurut Kotler dan Amstrong (2014:34) relationship marketing adalah keseluruhan proses membangun dan mempertahankan hubungan pelanggan yang menguntungkan dengan memberikan nilai pelanggan dan kepuasan pelanggan.Zeithml dan Bitner (2013:157) mendefinisikan relationship marketingorientasi strategis, yang memfokuskan pada mempertahankan dan mengembangkan pelanggan yang ada, lebih daripada menarik pelanggan baru.

\section{Citra Merek (Y)}

Brand image atau citra merek merupakan serangkaian sifat tangible dan intangible, seperti ide, keyakinan, nilainilai, kepentingan, dan fitur yang membuatnya menjadi unik (Hasan, 2013:210).Secara visual dan kolektif, sebuah brand image harus mewakili semua karakteristik internal dan eksternal yang mampu mempengaruhi bagaimana sebuah merek itu dirasakan oleh target pasar atau pelanggan (Hasan, 2013:210). 


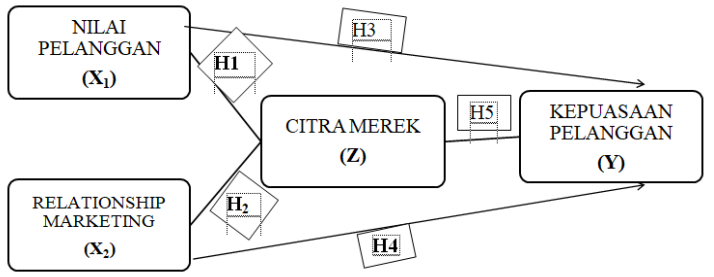

Gambar 1

Kerangka Konseptual

\section{Metode Penelitian}

Penelitian inidilakukan dalam penuliasan meliputi Nilai Pelanggan $\left(\mathrm{X}_{1}\right)$, Relationship Marketing ( $\mathrm{X}_{2}$ ), Kepuasaan Pelanggan ( Y ) dan Citra Merek (Z) dilakukan pada Keripik Balado BintangJaya 4 x 7 Padang usaha berada di alamat jalan belakang olo no.22, Padang Barat, Kota Padang, Sumatera Barat, 25117.Bintang Jaya 4 x 7 merupakan suatu usaha menjual produk keripik balado yang juga ikut bersaing dengan usaha keripik balado lainnya, tetapi usaha keripik balado Bintang Jaya 4 x 7 memilikibanyak pelanggan karena citra merek tersebut.MenurutSugiyono

(2015:148),Populasi adalah wilayah generalisasi yang terdiri atas: objek atau subjek yang mempunyai kuantitas dan karakteristik tertentu yang ditetapkan oleh peneliti untuk dipelajari dan kemudian ditarik kesimpulannya. Populasi juga bukan sekedar jumlah yang ada pada objek atau subjek yang dipelajari, tetapi meliputi seluruh karakteristik atau sifat yang dimiliki oleh subjek atau objek itu.Menurut Widiyanto (2012:58) Sampel merupakan bagian dari populasi yang ingin diteliti; dipandang sebagai suatu pendugaan terhadap populasi, namun bukan populasi itu sendiri.Sampel dianggap sebagai perwakilan dari populasi yang hasilnya mewakili keseluruhan gejala yang diamati.Sampel dalam penelitian ini adalah sebagian dari pelanggan yang telah membeli produk keripik balado pada bintang jaya $4 \times 7$ Padang.

Menurut Widiyanto (2012: 58) untuk ukuran populasi dalam penelitian yang tidak dapat diketahui dengan pasti jumlahnya maka besar sampel yang digunakan dapat dihitung dengan rumus sebagai berikut:

$$
\mathrm{N}=\frac{\mathrm{Z}^{2}}{4(\mathrm{Moe})^{2}}
$$

Dimana:

$$
\begin{aligned}
& \mathrm{n}=\text { ukuran sampel } \\
& \mathrm{Z}=1,96 \text { score pada tingkat } \\
& \text { signifikasi tertentu (derajat } \\
& \text { keyakinan ditentukan 95\%) } \\
& \text { Moe = Margin of error, tingkat }
\end{aligned}
$$
kesalahan mksimum $10 \%$

Dengan mengunakan rumus diatas, maka diperoleh perhitungan sebagai berikut

$$
\begin{gathered}
\mathrm{n}=\frac{(1,96)^{2}}{4(10 \%)^{2}} \\
\mathrm{n}=96,04=\begin{array}{l}
97 \text { atau dibulatkan } \\
100
\end{array}
\end{gathered}
$$

Maka sampel penelitian adalah 100 pelangan yang merupakan pelanggan di Keripik balado bintang jaya 4 x 7 Padang

\section{Teknik Analisis}

Di dalam penelitian ini, menggunakan analisis Partial Least Square (PLS) Structural Equation Modeling (SEM) dengan SmartPLS versi 3.0. Evaluasi PLS yaitu dengan menggunakan evaluasi inner model dan outer model.Outer Model merupakan model pengukuran untuk menilai validitas, parameter model pengukuran (validitas konvergen, validitas diskriminan, composite reliability dan Cronbach's alpha) sebagai parameter ketepatan model prediksi(Abdillah \& Hartono, 2015:193).

Convergent validity dari model pengukuran dengan model reflektif indikator dinilai berdasarkan loading factor (korelasi antara item score atau component score dengan construct score) yang dihitung dengan SmartPLS. Nilai convergent validity mengukur besarnya korelasi konstrak dengan variabel laten di mana dapat dilihat dari nilai loading factor yang diharapkan $>0.7$ sehingga dapat 
dikatakan ideal. Walaupun > 0.5 masih dapat diterima, sedangkan nilai loading factor $<0.5$ dapat dikeluarkan dari model.

Discriminant validity dari model pengukuran dengan refleksif indikator dinilai berdasarkan cross loading pengukuran dengan konstruk.Dikatakan memenuhi validitas diskriminan jika korelasi konstruk dengan item pengukuran lebih besar daripada ukuran konstruk lainnya. Selain itu cara lain untuk melihat model yang mempunyai discriminant validity yang cukup jika akar average variance extracted (AVE) untuk setiap konstruk lebih besar daripada korelasi antar konstruk dengan konstruk lainnya dalam model (Chin, Gopal, \& Salinsbury 1997 dalam Abdillah \& Hartono, 2015:196). Oleh karena itu untuk menilai discriminant validity adalah membandingkan nilai square root of Average Variance Extracted (AVE) setiap konstruk dengan korelasi antara variabel lainnya dalam model.

Dalam suatu penelitian reliabilitas pada SmartPLS, ada dua perlakuan yang berbeda untuk dua jenis indikator yaitu cara untuk indikator formatif dan cara untuk indikator reflektif. Uji reliabilitas di dalam penelitian ini menggunakan indikator reflektif dan berikut cara pengukurannya :Uji reliabilitas untuk mengukur indikator reflektif dalam PLS dapat menggunakan dua metode, yaitu Cronbach's alpha dan compositereliability.Cronbach'alpha mengukur batas bawah nilai reliabilitassuatu konstruk sedangkan composite reliability mengukur nilai sesungguhnya reliabilitas suatu konstruk. Suatu konstruk dikatakan reliabel jika nilai Cronbach's alpha harus lebih dari 0,6 dan nilai composite reliability harus lebih dari 0,7. (Abdillah \& Hartono,2015:196).

\section{Hasil Penelititan}

\section{Pengujian Inner Model (Structural Model) \\ Proses pengujian selanjutnya} adalah pengujian inner model atau model struktural yang bertujuan untuk mengetahui hubungan antar konstruk atau pengaruh antar variabel penelitian sebagaimana yang telah dihipotesiskan. Tahap awal dari model struktural adalahmengevaluasi model dengan memperhatikannilai $R$-Square untuk konstruk endogen dari pengaruh yang diterimanya dari konstruk eksogen.Berikut model struktural hasil uji dengan menggunakan SmartPLS :

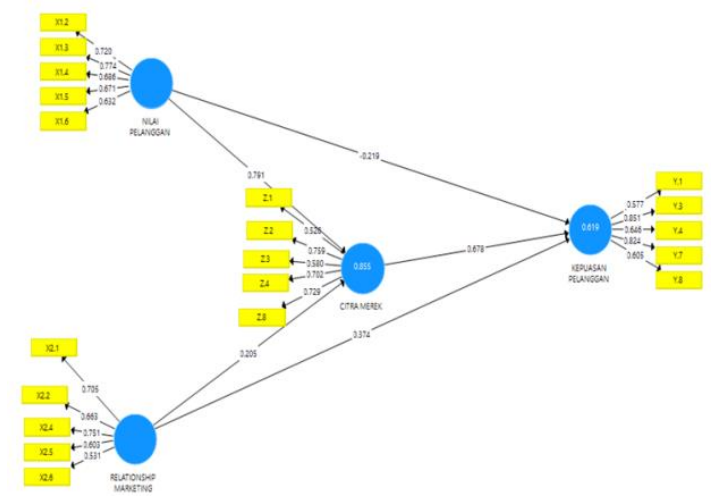

Sumber : Lampiran Hasil Pengolahan Data,Tahun 2019

\section{Gambar 2 Struktur model}

Berdasarkan Gambar , model struktur diatas dapat dibentuk Persamaan Model sebagai berikut :

a. Model Persamaan I, merupakan gambaran besarnya pengaruh konstruk Nilai pelanggan dan relationship marketing terhadap citra merek sebagai variabel intervening dengan koefisien yang ada ditambah dengan tingkat error yang merupakan kesalahan estimasi atau yang tidak bisa dijelaskan dalam model penelitian.

Citra Merek = $\beta_{1}$ Niliai Pelangant $\beta_{2}$ Relationship Marketing $+e_{1}$ ataul

Citra Merek $=0,791$ Nilai Pelangogan $+0,205$ Relationship Marketing $+e_{1}$ 
b. Model Persamaan II, merupakan gambaran besarnya Nilai pelanggan, Relationship Marketing, dan citra merek terhadap kepuasan pelanggan dengan masing-masing koefisien yang ada untuk masing-masing konstruk ditambah dengan error yang merupakan kesalahan estimasi

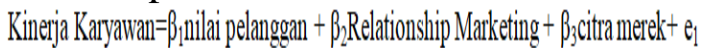

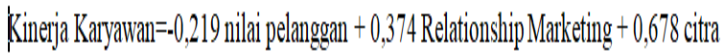 merelk $+e_{1}$}

Pengujian hipotesis bertujuan untuk menjawab permasalahan yang ada dalam penelitian ini yaitu pengaruh konstruk laten eksogen tertentu dengan konstruk laten endogen tertentu baik secara langsung maupun secara tidak langsung melalui variabel intervenig. Pengujian hipotesis pada penelitian ini, dapat dinilai dari besarnya nilai t-statistik atau t-hitung dibandingkan dengan t-tabel 1.96 pada alpha 5\%. Jika t-statistik/t-hitung < t-tabel 1.96 pada alpha 5\%, maka Ho ditolak dan Jika t-statistik/t-hitung > t-tabel 1.96 pada alpha 5\%, maka Ha diterima. Berikut hasil output SmartPLS, yang mengambarkan output estimasi untuk pengujian model structural pada Tabel 2 :

\begin{tabular}{|c|c|c|c|c|c|}
\hline \multicolumn{6}{|c|}{$\begin{array}{c}\text { Tabel.2 } \\
\text { Result For Inner Weights } \\
\text { Untuk Pengaruh Langsung (Direct Effect) }\end{array}$} \\
\hline Hipotesis & Uraian & $\begin{array}{l}\text { Original } \\
\text { Sample } \\
(\mathrm{O})\end{array}$ & $\begin{array}{c}\text { Standard } \\
\text { Deviation } \\
\text { (STDEV) }\end{array}$ & $\underset{\text { Statistics }}{\mathrm{T}}$ & Keterangan \\
\hline 1 & $\begin{array}{l}\text { Citra Merek - } \\
\text { >Kepuasan } \\
\text { Pelanggan }\end{array}$ & 0.678 & 0.262 & 2.591 & $\begin{array}{l}\text { Hipotesis } \\
\text { Diterima }\end{array}$ \\
\hline 2 & $\begin{array}{l}\text { Nilai Pelanggan - } \\
\text { >Citra Merek }\end{array}$ & 0.791 & 0.047 & 16.972 & $\begin{array}{l}\text { Hipotesis } \\
\text { Diterima }\end{array}$ \\
\hline 3 & $\begin{array}{l}\text { Nilai Pelanggan - } \\
\text { >Kepuasan } \\
\text { Pelanggan }\end{array}$ & -0.219 & 0.238 & 0.920 & $\begin{array}{c}\text { Hipotesis } \\
\text { Ditolak }\end{array}$ \\
\hline 4 & $\begin{array}{l}\text { Relationship } \\
\text { Marketing->Citra } \\
\text { Merek }\end{array}$ & 0.205 & 0.055 & 3.749 & $\begin{array}{l}\text { Hipotesis } \\
\text { Diterima }\end{array}$ \\
\hline 5 & $\begin{array}{l}\text { Relationship } \\
\text { Marketing- } \\
\text { >Kepuasan } \\
\text { Pelanggan }\end{array}$ & 0.374 & 0.088 & 4.259 & $\begin{array}{l}\text { Hipotesis } \\
\text { Diterima }\end{array}$ \\
\hline
\end{tabular}

padaTabel 2terlihat hasil pengujian hipotesis penelitian dimulai dari hipotesis pertama, kedua, keempat, dengan hipotesis kelima yang memiliki pengaruh secara langsung dengan variabel konstruk nilai pelanggan, relationship marketing, dan citra merek terhadap kepuasan pelanggan.
Temuan keempat hipotesis penelitian tersebut bahwa hipotesis yang ada dapat diterima dengan kata lain $\mathrm{H}_{0}$ ditolak dan $\mathrm{H}_{\mathrm{a}}$ diterima, karena nilai $\mathrm{T}$ statistic atau $\mathrm{T}$ hitungnya $>$ dari kesalahan menolak data pada $\mathrm{T}$ tabel sebesar 1,96. Dengan demikian dapat diartikan terdapat pengaruh positif dan signifikan Nilai pelanggan, Relationship Marketing, dan citra merek terhadap kepuasan pelanggan pada Keripik balado 4 x 7 Padang. Namun ada juga hasil pengujian hipotesa penelitian dari hipotesa ketiga tidak memiliki pengaruh secara langsungnilai pelanggan, relationship marketing, dan citra merek terhadap kepuasan pelanggan dimana nilai $\mathrm{T}$ statistic atau $\mathrm{T}$ hitungnya $<$ dari kesalahan menerima data pada $\mathrm{T}$ tabel sebesar 1,96.

Selanjutnya hasil SmartPLS untuk pengaruh tidak langsung (indirect effect), dijelaskan oleh nilai total effect yaitu gambaran pengaruh langsung ditambah dengan pengaruh tidak langsung melalui variabel intervening yang dalam hal ini adalah variabel citra merek, atau merupakan gambaran pengaruhnilai pelanggan, dan relationship marketing, terhadap kepuasan pelanggan melalui citra merek pada keripik balado bintang jaya 4 X 7 Padang.

Selanjutnya hasil SmartPLS untuk pengaruh tidak langsung (indirect effect), dijelaskan oleh nilai total effect yaitu gambaran pengaruh langsung ditambah dengan pengaruh tidak langsung melalui variabel intervening yang dalam hal ini adalah variabel citra merek, atau merupakan gambaran pengaruh nilai pelanggan, dan relationship marketing, terhadap kepuasan pelanggan melalui citra merek pada keripik balado bintang jaya 4 X 7 Padang. (hipotesis 6 dan 7).

\begin{tabular}{|c|c|c|c|c|c|}
\hline $\begin{array}{l}\text { Hpote } \\
\text { sis }\end{array}$ & Uraian & $\begin{array}{l}\text { Original } \\
\text { Sample } \\
\text { (O) }\end{array}$ & $\begin{array}{l}\text { Standard } \\
\text { Deviation } \\
\text { (STDEV) }\end{array}$ & Statistics & Keterangan \\
\hline 1 & $\begin{array}{l}\text { Nilai Pelanggan->Citra } \\
\text { Merek ->Kepuasan } \\
\text { Pelanggan }\end{array}$ & 0.536 & 0.211 & 2.541 & $\begin{array}{c}\text { Hipotesis } \\
\text { Diterima }\end{array}$ \\
\hline 2 & $\begin{array}{l}\text { Relationship Marketing- } \\
>\text { Citra Merek ->Kepuasan } \\
\text { Pelanggan }\end{array}$ & 0.139 & 0.067 & 2.091 & $\begin{array}{c}\text { Hipotesis } \\
\text { Diterima }\end{array}$ \\
\hline
\end{tabular}


Hasil pengujian data untuk pengaruh tidak langsung (indirect effect) untuk kedua hipotesis di atas, juga menyimpulkan bahwa terdapat pengaruh positif dan signifikan nilai pelanggan terhadap kepuasan pelanggan melalui citra merek, begitu juga dengan terdapat pengaruh positif dan signifikan relationship marketing, terhadap kepuasan pelanggan melaluicitra merek. Dengan kata lain variabelcitra merek sebagai variabel intervening mampu memediasi atau memperkuat pengaruh nilai pelanggan, dan relationship marketing, terhadap kepuasan pelanggan pada keripik balado bintang jaya 4 X 7 Padang Ini dapat dibuktikan dari nilai $\mathrm{T}$ statistik kedua hipotesis di atas yang nilainya besar dari $\mathrm{T}$ tabel sebesar 1,96.

\section{Pengaruh Nilai Pelanggan terhadap Citra Merek}

Ringkasan hasil pengujian SmartPLS di atas, ditemukan pengaruh positif dan signifikan nilai pelanggan terhadap citra merek pada keripik balado bintang jaya 4 × 7 Padang, dengan nilai koefisien regresi sebesar 0.791 yang merupakan besarnya pengaruh yang diberikan konstruk nilai pelanggan dalam pembentukan citra merek keripik balado bintang jaya 4 x 7 Padang. Sedangkan nilai standar error sebesar 0.047 merupakan tingkat kesalahan estimasi yang tidak dapat dijelaskan oleh konstruk ini, sedangkan nilai t-statistik atau t-hitung sebesar 16.972. Jika dibandingkan nilai tstatistik atau t-hitung dengan t-tabel sebesar 1.96 pada alpha 5\%, maka nilai tstatistik > t-tabel 1.96 atau $16.972>1.96$ pada alpha 5\%.Sedangkan jika diamati arah hubungan kedua variabel penelitian di atas juga masih berpengaruh positif, yang artinya jika semakin tinggi penerapan dan dukungan darinilai pelanggan terhadap citra merek, maka hal ini akan berdampak semakin tinggi citra merek yang dimiliki oleh usaha keripik balado tersebut. Sebaliknya jika semakin dari nilai pelaggan dalam memuaskan keinginan pelanggan dalam sebuah produk keripik balado, maka hal ini juga akan ada kecenderungan semakin rendah citra merek dalam pelaksanaan tugas proses penjualan produk keripik balado ke pelanggan.Hasil hipotesis ini juga sesuai dengan kajian teoritis yang dijelaskan oleh Ryu dkk. (2012) juga menunjukkan hasil yang sama, nilai pelanggan berpengaruh secara positif terhadap citra perusahaan. Ini menunjukkan bahwa nilai pelanggan mempunyai pengaruh yang besar dalam membangun citra merek.Berbagai penelitian juga telah dilakukan untuk menguji nilai pelanggan, hasilnya nilai pelanggan berpengaruh secara signifikan terhadap citra merek.

\section{Pengaruh Relationship marketing terhadap citra merek}

Hasil pengujian SmartPLS di atas, ditemukan pengaruh positif dan signifikan pengaruh relationship makrketing terhadap citra merek pada keripik balado bintang jaya 4 x 7 Padang, dengan nilai koefisien regresi sebesar 0,205 yang merupakan besarnya pengaruh yang diberikan konstruk relationship makrketing terhadap citra merek pada bintang jaya keripik balado 4 x 7 Padang, Sedangkan nilai standar error sebesar 0.055 merupakan tingkat kesalahan estimasi yang tidak dapat dijelaskan oleh konstruk ini, sedangkan nilai t-statistik atau t-hitung sebesar 3,749. Jika dibandingkan nilai tstatistik atau t-hitung dengan t-tabel sebesar 1.96 pada alpha 5\%, maka nilai tstatistik > t-tabel 1.96 atau 3,749> 1.96 pada alpha 5\%.Oleh karena itu, temuan empiris ini juga menyatakan bahwa relationship makrketing merupakan salah satu faktor yang menentukan dan mempengaruhi citra merek karena usaha keripik balado 4 x 7 padang mampu membangun dan mempertahankan hubungan pelanggan yang mampu membangun hubungan yang baik. Dengan kata lain usaha keripik balado 4 x 7 
Padang harus dapat memaksimalkan relationship marketing untuk dapat citra merek untuk bekerja secara optimal guna mencapai tujuan usaha keripik balado yang lebih tinggi.

\section{Pengaruh Nilai Pelanggan terhadap Kepuasan Pelanggan}

Hasil pengujian data dengan menggunakan SmartPLS, menemukan nilai koefisien nilai pelanggan sebesar 0.219 yang merupakan rendahnya pengaruh yang diberikan konstruk nilai pelanggan terhadap kepuasan pelanggan pada keripik balado bintang jaya 4 x 7 Padang. Dimana nilai standar error sebesar 0.238 merupakan tingkat kesalahan estimasi yang tidak dapat dijelaskan oleh konstruk ini, sedangkan nilai t-statistik atau t-hitung sebesar 0,920. Jika dibandingkan nilai t-statistik atau thitung dengan t-tabel sebesar 1.96 pada alpha 5\%, maka nilai t-statistik > t-tabel 1.96 atau 0,920> 1.96 pada alpha 5\%. Dengan demikian dapat disimpulkan bahwa nilai pelanggan terhadap tidak memiliki pengaruh signifikan terhadap kepuasan pelanggan pada keripik balado bintang jaya 4 x 7 Padang .

\section{Pengaruh Relationship marketing terhadap Kepuasan Pelanggan}

Hasil pengujian data dengan menggunakan SmartPLS pada Tabel 4.24, menemukan nilai koefisien relationship marketing sebesar 0,374 yang merupakan rendahnya pengaruh yang diberikan konstruk relationship marketing terhadap kepuasan pelanggan pada keripik baladobintang jaya 4 x 7 Padang. Dimana nilai standar error sebesar 0.088 merupakan tingkat kesalahan estimasi yang tidak dapat dijelaskan oleh konstruk ini, sedangkan nilai t-statistik atau t-hitung sebesar 4,259. Jika dibandingkan nilai tstatistik atau t-hitung dengan t-tabel sebesar 1.96 pada alpha 5\%, maka nilai tstatistik > t-tabel 1.96 atau 4,259> 1.96 pada alpha 5\%. Dengan demikian dapat disimpulkan relationship marketing terhadap kepuasan pelanggan pada keripik balado bintang jaya $4 \times 7$ Padang .

\section{Pengaruh Citra Merek terhadap Kepuasan Pelanggan \\ Berdasarkan hasil pengujian SmartPLS} di atas, ditemukan pengaruh positif dan signifikanpengaruh citra merek terhadap kepuasan pelanggan pada keripik baladobintang jaya $4 \times 7$ Padang, dengan nilai koefisien regresi sebesar 0,678 yang merupakan besarnya pengaruh yang diberikan konstruk relationship makrketing terhadap citra merek pada bintang jaya keripik balado 4 × 7 Padang, Sedangkan nilai standar error sebesar 0.262 merupakan tingkat kesalahan estimasi yang tidak dapat dijelaskan oleh konstruk ini, sedangkan nilai t-statistik atau t-hitung sebesar 2,591. Jika dibandingkan nilai tstatistik atau t-hitung dengan t-tabel sebesar 1.96 pada alpha 5\%, maka nilai tstatistik > t-tabel 1.96 atau 2,591> 1.96 pada alpha 5\%.Penelitian yang dilakukan oleh Hung-Che Wu (2014), pada penelitiannya variabel citra merek secara signifikan berpengaruh terhadap kepuasan pelanggan. Ini membuktikan semakin baik citra perusahaan akan berpengaruh secara positif terhadap kepuasan pelanggan.

\section{Pengaruh Nilai Pelanggan terhadap Kepuasan Pelanggan melalui Citra Merek}

Berdasarkan hasil pengujian SmartPLS pada Tabel 4.26 di atas, ditemukan pengaruh positif dan signifikan nilai pelanggan terhadap kepuasan pelanggan melalui citra merekpada keripik $\begin{array}{lllll}\text { balado bintang jaya } 4 & \text { x } & 7\end{array}$ Padang.dengannilai koefisien regresi sebesar 0.536 yang merupakan besarnya pengaruh yang diberikan konstruk citra merek dalam memediasi pengaruh nilai pelanggan terhadap kepuasan pelanggan padakeripik balado bintang jaya 4 x 7 Padang.Sedangkan nilai standar error sebesar 0.211 merupakan tingkat kesalahan estimasi yang tidak dapat dijelaskan oleh konstruk ini, sedangkan 
nilai t-statistik atau t-hitung sebesar 2,541. Jika dibandingkan nilai t-statistik atau thitung dengan t-tabel sebesar 1.96 pada alpha 5\%, maka nilai t-statistik > t-tabel 1.96 atau 2,541> 1.96 pada alpha 5\%. Dengan demikian dapat dikatakan bahwa citra merek terlihat mampu memediasi pengaruh nilai pelanggan dalam meningkatkan kepuasan pelanggan.Oleh karena itu pengaruh terbaik dari hipotesis ini adalah pengaruh tidak langsung atau nilai pengaruh tidak langsung lebih baik dibanding nilai pengaruh langsung.

\section{Pengaruh Relationship Marketing terhadap Kepuasan Pelanggan melalui Citra Merek}

Berdasarkan hasil pengujian SmartPLS pada Tabel 4.di atas, ditemukan pengaruh positif dan signifikanrelationship marketing terhadap kepuasan pelanggan melalui citra merek pada keripik balado bintang jaya $4 \times 7$ Padang.dengannilai koefisien regresi sebesar 0.139 yang merupakan besarnya pengaruh yang diberikan konstruk citra merek dalam memediasi pengaruh relationship marketing terhadap kepuasan pelanggan pada keripik balado bintang jaya 4 × 7 Padang.Sedangkan nilai standar error sebesar 0.067 merupakan tingkat kesalahan estimasi yang tidak dapat dijelaskan oleh konstruk ini, sedangkan nilai t-statistik atau t-hitung sebesar 2,091. Jika dibandingkan nilai t-statistik atau thitung dengan t-tabel sebesar 1.96 pada alpha 5\%, maka nilai t-statistik > t-tabel 1.96 atau 2,091> 1.96 pada alpha 5\%. Dengan demikian dapat dikatakan bahwa citra merek terlihat mampu memediasi pengaruh relationship marketing dalam meningkatkan kepuasan pelanggan. Oleh karena itu pengaruh terbaik dari hipotesis ini adalah pengaruh tidak langsung atau nilai pengaruh tidak langsung lebih baik dibanding nilai pengaruh langsung

\section{Kesimpulan}

Berdasarkan hasil pengujian dan pembahasan hipotesis, dapat diperoleh kesimpulan sebagai berikut:Terdapat pengaruh secara langsung nilai pelanggandan relationship marketingterhadap citra merek keripik balado bintang jaya 4 x 7 Padang. Tidak terdapat pengaruh secara langsung nilai pelanggan dan relationship marketing terhadap kepuasan pelanggan keripik balado bintang jaya 4 x 7 Padang. Kemudian juga Terdapat pengaruh citra merek terhadap kepuasan pelanggan keripik balado bintang jaya 4 x 7 Padang. Untuk pengaruh tidak langsung ditemukan, terdapat nilai pelanggan terhadap kepuasan pelanggan melalui citra merek pada keripik balado bintang jaya 4 x 7 Padang dan juga terdapat nilai pelanggan terhadap kepuasan pelanggan melalui citra merek pada keripik balado bintang jaya $4 \times 7$ Padang.

\section{DAFTAR PUSTAKA}

Abdillah, W., dan J. Hartono. 2015. Partial Least Square (PLS). Penerbit Andi. Yogyakarta.

Ali Hasan, 2013, Marketing, Cetakan Pertama, Media Pressdindo Yogyakarta

Ghozali, Imam (2006). Struktur Equation Modeling, Metode alternative dengan Partial Least Aquares, Edisi 1, Universitas Diponegoro.

Ismail, Muhammad. 2012. Strategi Pemasaran untuk Membangun Citra dan Loyalitas Merek, Survei pada Pelanggan Provider Seluler GSM Prabayar Telkomsel, Indosat, dan XL di Makassar. Bogor: IPB Press.

Kotler, P., dan Armstrong, Gary. 2012.

Marketing Management. England: Pearson.

Kotler, Philip dan Armstrong, Gary. 2014. Principles of Marketing.15th Edition.Pearson, New Jersey 
Kotler, Philip dan Keller. 2012. Manajemen Pemasaran. Edisi 12. Jakarta: Erlangga.

Leliga, F. J. 2013. "Analisa Pengaruh Brand Image terhadap Customer".Dalam Jurnal Hospitality dan Manajemen Jasa.Bali.Vol 1, No 1.

Rizan, M., Warokka, A \& Listyawati, D. 2014. Relationship Marketing and Customer Loyalty: Do Customer Satisfaction and Customer Trust Really Serve as Intervening Variables?.Journal ofMarketing Research \& Case Studies.

Ryu, K., Lee, H. R \& Gon Kim, W. 2012. The Influence of the Quality of the Physical Environment, Food, and Service on Restaurant Image, Customer Perceived Value, Customer Satisfaction, and Behavioral Intentions. International Journal of Contemporary Hospitality Management. 24 (2): 200-223.

Sugiyono. 2014. Metode Penelitian Kuantitatif, Kualitatif, dan $R \& D$. Bandung: Alfabeta.

Sugiyono. 2015. Metode Penelitian Kombinasi. Bandung: Alfabeta

Tjiptono,Fandy. 2014. Pemasaran Jasa. Yogyakarta: penerbit ANDI
Umar, Husein. 2014. Metode Penelitian untuk Skripsi dan Tesis.Edisi 2.Cetakan $13 . \quad$ Jakarta: Rajawali Pers.

Usman, Husaini dan Akbar Setiady Purnomo. 2012. Pengantas Statistika. Edisi 2. Jakarta. Bumi Aksara.

Vegholm, F. 2011. Relationship Marketing and The Management of Corporate Image in The BankSME Relationship. Management Research Review.34 (3).

Widiyanto, M.A. (2013). Statistika Terapan, Konsep dan Aplikasi SPSS/Lisrel dalam Penelitian Pendidikan, Psikologi dan Ilmu Sosial Lainya.Jakarta : PT Elex Media Komputindo.

$\mathrm{Wu}$, Hung-Che. 2014. The effects of customer satisfaction, perceived value, corporate image and service quality on behavioral intentions in gaming establishments. Asia Pacific Journal of Marketing and Logistics. 26 (4): 540 - 565.

Zeithml, Valerie A., Mary Jo Bitner, dan Dwayne D. Gremler 2013. Service Marketing.Singapura : McGraw-Hill Education (Asia) 